
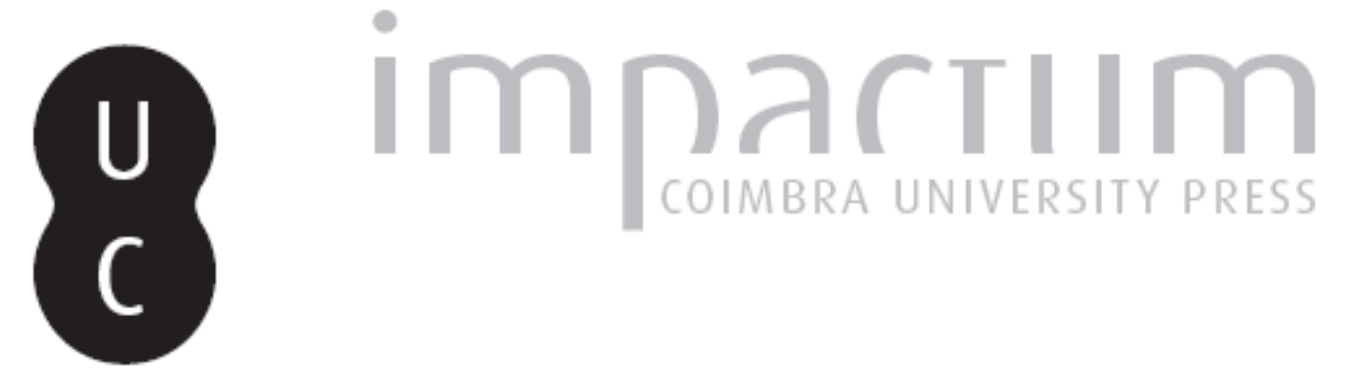

\title{
O Nilo na literatura Grega
}

\section{Autor(es): Silva, Maria de Fátima}

Publicado por: Centro de História da Universidade de Lisboa

URL persistente:

URI:http://hdl.handle.net/10316.2/23743

DOI:

DOI:http://dx.doi.org/10.14195/0871-9527_20_18

Accessed : $\quad$ 26-Apr-2023 02:46:23

A navegação consulta e descarregamento dos títulos inseridos nas Bibliotecas Digitais UC Digitalis, UC Pombalina e UC Impactum, pressupõem a aceitação plena e sem reservas dos Termos e Condições de Uso destas Bibliotecas Digitais, disponíveis em https://digitalis.uc.pt/pt-pt/termos.

Conforme exposto nos referidos Termos e Condições de Uso, o descarregamento de títulos de acesso restrito requer uma licença válida de autorização devendo o utilizador aceder ao(s) documento(s) a partir de um endereço de IP da instituição detentora da supramencionada licença.

Ao utilizador é apenas permitido o descarregamento para uso pessoal, pelo que o emprego do(s) título(s) descarregado(s) para outro fim, designadamente comercial, carece de autorização do respetivo autor ou editor da obra.

Na medida em que todas as obras da UC Digitalis se encontram protegidas pelo Código do Direito de Autor e Direitos Conexos e demais legislação aplicável, toda a cópia, parcial ou total, deste documento, nos casos em que é legalmente admitida, deverá conter ou fazer-se acompanhar por este aviso.

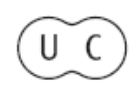




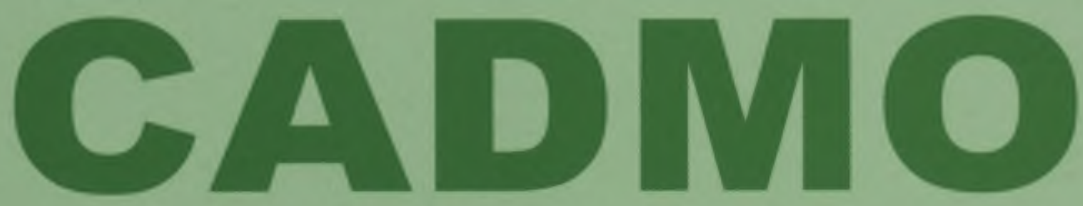

Revista de História Antiga

\author{
Centro de História \\ da Universidade de Lisboa
}

\title{
20
}

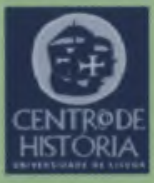

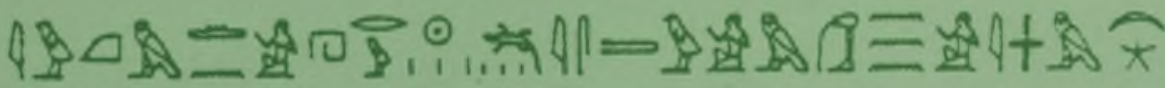

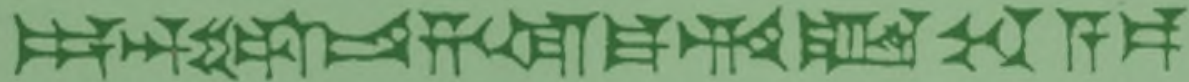

MHNIN AEI $\Delta$ E $\Theta E A ~ \Pi H \Lambda H I A \triangle E \Omega$ 


\title{
O NILO NA LITERATURA GREGA
}

\author{
MARIA DE FÁTIMA SILVA \\ Universidade de Coimbra \\ fanp@ci.uc.pt
}

\begin{abstract}
Dedicaram-Ihe festas e exaltaram o Nilo, a que chamavam Hórus, o alimentador de todo o Egipto: do Alto, o salvador, do Baixo, o pai e criador, que todos os anos traz um novo lodo (véav ìúv), de onde o nome grego do Nilo.
\end{abstract}

Heliodoro, Etiópicas 9. 22. 5

\section{Resumo}

A importância e grandeza do Nilo sempre exerceu sobre os Gregos, um povo que não conhecia, na sua paisagem, cursos de água relevantes, um enorme fascínio. Por isso toda a literatura grega, ao longo dos séculos, se Ihe refere com insistência e Ihe dedica uma constante atenção.

Palavras-chave: Nilo; nascentes; cheias; delta; literatura grega.

\section{Abstract}

The importance and volume of the Nile was always fascinating to the Greeks, a people that didn't knew, in their own landscape, such a relevant river. It is why Greek Literature along the centuries mentions it insistently.

Keywords: Nile; sources; flood; delta; greek literature. 
O deslumbramento que o Nilo causou entre os Gregos em toda a Antiguidade (desde o século VIII a. C. que havia gregos no delta activos no comércio) tem testemunho nas inúmeras referências que the são feitas ao longo dos séculos nos mais diversos géneros literários. Depois de alusões breves nos poemas homéricos, em plena época clássica Heródoto dedica ao Egipto, como é sabido, todo o Livro II das suas Histórias, onde o Nilo merece uma atenção incontornável; fazia-se, de resto, eco de opiniões emitidas por filósofos e geógrafos seus contemporâneos. O mesmo historiador deixa subentendido 0 interesse de um trágico como Ésquilo pelas velhas lendas egípcias (2. 156; cf. Paus. 8. 37. 6); da veracidade dessa preferência dão testemunho as menções que Ihes são feitas em Persas, Suplicantes e Prometeu. Eurípides, por seu lado, situa no Egipto a sua Helena, que abre com a menção do Nilo. Por fim, séculos mais tarde, quando a novela prosperava como fenómeno literário da época helenística, o Nilo, entendido como logótipo do Egipto, reapareceu com frequência, decerto mais uma vez inspirado pelas referências constantes dos geógrafos da época.

Os motivos para esse interesse em volta do Nilo são de vária ordem. Em primeiro lugar, a própria natureza do rio, o volume do seu caudal, a regularidade do seu curso ${ }^{(1)}$ enquadrado por um enorme deserto, a beleza das suas águas eram de molde a impressionar sobretudo uma Hélade carecida de rios significativos. Mas além disso, o Nilo identificava o país que Ihe devia a existência, de que os Gregos reconheciam a civilização superior e de que sabiam ter importado algumas das suas marcas culturais mais relevantes. Se havia afinidades, as diferenças eram também significativas, desde logo no que respeita às condições naturais - clima, fauna e flora; e, nesse aspecto, o Nilo tinha uma interferência decisiva numa certa paisagem e na vida que a povoava. Pela própria insistência com que o rio egípcio é referido, criou-se em sua volta um desenho mítico convencional, que, ao longo dos séculos, se foi afinando, sem no entanto se afastar muito de uma configuração determinada.

Consideremos, em primeiro lugar, os epítetos que a literatura the associou. Méyas (A. Pers. 33, Supp. 879-880; Hdt. 2. 10. 3) é alusivo à extensão e volume, que o põem, em termos de tamanho, em vantagem sobre outros cursos de água ainda que também significativos ${ }^{(2)}$. Este, que é o traço elementar da sua natureza, deu-lhe o direito a outros atributos, de onde sobressai a capacidade "fecundante" de que, como nenhum outro, deu provas: $\pi \circ \lambda v \theta \rho \epsilon ́ \mu \mu \omega \nu$ (A. Pers. 33); Heródoto 
2. 11. 4 louva-o como "grande e activo", fama que persistiu ao longo dos séculos e que regressa, já no romance helenístico, com a chancela de Delfos. Ao dirigir-se a alguém que provinha do Egipto, a Pítia podia dizer (Heliod. 2. 26. 5); "Vens das margens férteis do Nilo"

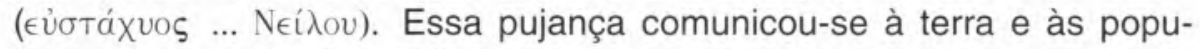
lações que com ele confinavam, como dádiva de um deus. As suas

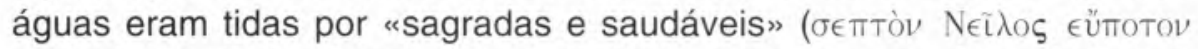

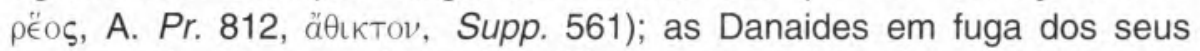
perseguidores masculinos identificam-nas como "águas fecundas"

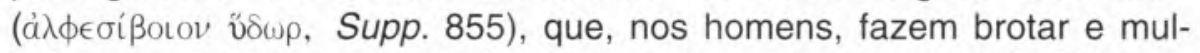

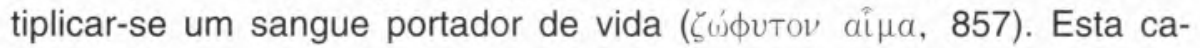
pacidade de estimular a fertilidade é, no caso das filhas de Dânao, uma ameaça. Um escoliasta recorda que a água do Nilo favorece os nascimentos, sobretudo de crianças do sexo masculino; e o mito consagrou-lhe este potencial, ao sublinhar que foi depois de a ter bebido que Zeus gerou Ares. Heliodoro (2. 26. 5) refere essa mesma fertilidade com o epíteto, aplicado ao solo egípcio, de кuavaúlakos, "de sulcos negros" ${ }^{(3)}$. As suas águas impuseram-se pela beleza e pureza, que os poetas se não cansaram de celebrar. Eurípides (Hel. 1-3) fala das

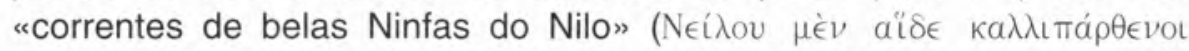
poaí) $)^{(4)}$, atribuindo-Ihes características tradicionais pela menção das divindades que o povoam; para mais adiante as referir como "o claro espelho do Nilo" (Hel. 462-463), no que a W. Allan ${ }^{(5)}$ soa como uma manifestação de orgulho da velha porteira do palácio de Teoclímeno pelo rio da sua terra, perante o desconhecimento e angústia de um recém-chegado Menelau, desatento às maravilhas que o rodeiam. Da pureza das águas do Nilo nasceu um costume sacro, referido por Aquiles Tácio 4. 18. 3-6, de se beber da concha da mão, sem qualquer interferência ou intermediário, a água sagrada do rio.

Nada mereceu aos antigos maior discussão, no que ao Nilo se refere, do que o fenómeno das suas cheias. O próprio ritmo do crescimento ou recuo das águas, que parecia obedecer a uma sequência paradoxal - mais cheio no Verão e mais baixo no Inverno - desencadeou especulações científicas, de que os poetas abonam a popularidade. Na já referida abertura de Helena (1-3), Eurípides faz-se eco de uma das teorias mais propaladas, a do degelo das neves no Verão: "Estas são do Nilo as correntes de belas Ninfas que, quando chega a estação em que a branca neve degela, alaga, em vez das chuvas de Zeus, a planície do Egipto". Anos mais tarde, em 408, no prólogo do Arquelau (fr. $228 \mathrm{~N}^{2}$ ), Eurípides insiste na mesma afirmação, precisando 
desta vez que o processo ocorre na Etiópia, onde se situam as nascentes do rio (cf., no mesmo sentido, A. fr. 300. 3-5 Radt; S. fr. 882 Radt).

Heródoto dá à questão das cheias do Nilo uma grande visibilidade. Acentua bem R. Thomas ${ }^{(6)}$ que o Nilo constituía para os Gregos

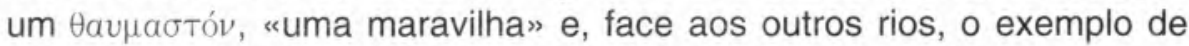
uma physis excepcional. Na verdade, Heródoto raciocina com base em leis universais, que levam a natureza a produzir fenómenos constantes e, por isso, compreensíveis. Como visitante curioso e interessado do país dos faraós, o historiador não encontrou, apesar dos seus esforços, quem, no Egipto, Ihe pudesse dar para o fenómeno uma explicação satisfatória (2. 19. 1): "Sobre a natureza do rio não consegui nenhuma informação, nem dos sacerdotes nem fosse de quem fosse". E, no entanto, a questão suscitada era precisa (2. 19. 2) ${ }^{(7)}$ : "Eis sobre o que eu pretendia que me informassem: porque é que, durante cem dias após o solstício de Verão, o Nilo sobe e provoca inundações e, passado este período, se retira e baixa de novo, de modo a, durante o Inverno e até ao solstício do Verão seguinte, se manter com pouco volume ${ }^{(8)}$. A que acrescenta um outro ponto relacionado com este: porque é que, ao contrário dos outros rios, este não produz ventos devido ao calor $(2.19 .3,2.27 .1)^{(9)}$ ?

$\mathrm{O}$ que decerto os sacerdotes the poderiam sugerir teria um carácter religioso ou místico e não satisfazia o seu desejo de uma explicação de natureza científica. Volta-se então para as teorias aventadas pelos sábios gregos ${ }^{(10)}$ que, na sua multiplicidade, patenteiam o interesse generalizado que o assunto mereceu, em conformidade, de resto, com a expansão que também as Histórias the dão (2. 19-27). Sem dúvida que os Milésios, pela proximidade geográfica com o Egipto, seriam os Gregos não residentes no país dos faraós que melhor conheciam o Nilo. Sendo Mileto a sede da filosofia iónica, não surpreende que as teorizações de referência sobre os fenómenos associados ao rio tivessem aí a sua origem. Embora Heródoto não associe cada uma das teorias que vai enunciar a um autor concreto, alguns nomes de filósofos da lónia parecem incontornáveis. Thomas 2000: 136 inclui entre as possibilidades Tales de Mileto, do séc. VII-VI a. C., Anaxágoras (a quem parece de associar a teoria do degelo já referida a propósito da Helena de Eurípides; cf. D. S. 1. 38. 4), e, como reflexo das mesmas teorias já em finais do século V, Diógenes de Apolónia e Enópides de Quios. Apesar das reservas que algumas dessas hipóteses Ihe merecem ${ }^{(11)}$, Heródoto faz delas um registo interessante. Como primeira teoria (2. 20. 2-3), cita Tales (DK A11, 16; cf. D. S. 1. 38. 
2) ${ }^{(12)}$, mais tarde retomado por Eutímenes de Marselha (FGrHist 647F $1,5)$. De acordo com esta corrente, são os ventos etésios, "anuais", que sopram do quadrante noroeste, os responsáveis pelas cheias, ao impedirem o Nilo de desaguar no mar e lhe fazerem refluir as águas. São vários, e convincentes, os argumentos de Heródoto contra esta versão: com ou sem ventos, o Nilo sobe da mesma forma, além de que o mesmo se não passa com outros rios orientados na mesma direcção sul-norte e sujeitos a condições semelhantes (D. S. 1. 38. 3 repete o mesmo ponto de vista). Uma segunda teoria (2. 21) se sucede a esta, mais fantástica e menos credível, a de Hecateu de Mileto (FGrHist 1F 302) que, segundo A. B. Lloyd e A. Fraschetti ${ }^{(13)}$, talvez retomasse a de Eutímenes. Essa fazia do Oceano, o rio que segundo a tradição circunda a Terra, a fonte do Nilo e a razão das inundações provocadas pelos mesmos ventos. Semelhante à anterior, esta teoria entrava em linha de conta com o Oceano circundante (cf. II. 18. 607$-608,21.195-197$ - que dá o Oceano por origem "de todos os rios, de todo o mar, de todas as fontes e de todas as nascentes profundas"; Hes. Th. 337-345; Hdt. 4. 8. 2). Esta é uma hipótese que Heródoto ridiculariza (2. 23, 4. 36. 2) como invenção poética que ascende a Homero(14); falta-Ihe, na sua perspectiva, comprovação empírica, porque ninguém verificou a existência de tal rio. Em terceiro lugar (2. 22) é enunciada a opinião de Anaxágoras (DK 59, A 45, 5, A 91), decerto muito difundida no século $\mathrm{V}$, como revela a alusão que the é feita na tragédia. Este ponto de vista, tomado por Heródoto como pura ficção, tem, de acordo com o que hoje sabemos, veracidade. Segundo esta teoria (cf. D. S. 1. 38. 4), o Nilo é o produto de um degelo que ocorreria na Líbia, onde o curso do rio tem a sua origem. Heródoto salienta o que de absurdo ela contém quando provas não faltam de que se trata de uma das regiões mais quentes do mundo: os ventos, quentes, que dela sopram, a falta de chuva e de neve que a caracteriza, a cor negra da pele dos seus habitantes, ou os voos migratórios das aves que nela se refugiam no Inverno, enquanto as que são naturais da região se não deslocam.

Muito crítico sobre qualquer uma das três teorias em circulação, Heródoto aventa também a sua própria, a que assiste alguma verosimilhança (2. 24-26). De certa forma, a posição que defende parece advir de uma antiga tradição, de que a Odisseia é testemunha; o poema épico fala do Nilo com o epíteto de "rio alimentado pelo céu» (4. 477, 581). Segundo o historiador, a incidência do sol sobre a África durante o Inverno é tal que torna a região particularmente seca e os seus rios 
pobres de água. Em função das condições particulares desse continente, o sol actua no Inverno como se se tratasse do Verão, vaporizando a água ${ }^{(15)}$. Depois de dispersos, esses vapores ficam sujeitos ao efeito dos ventos do sul, mais frescos e mais húmidos, que os empurram para norte e provocam uma precipitação abundante. Esta é a situação de Inverno. No Verão, o sol ascende de novo às alturas do céu e sujeita a um efeito semelhante todos os rios; apenas enquanto os restantes, com a falta de chuva, tendem a secar, o Nilo, que não recebe chuva nem de Inverno nem de Verão, é o único que tem mais água do que no inverno, altura em que o efeito de vaporização é mais intenso (cf. Corcella 1984: 80). É esta a causa natural - o sol e a evaporação que provoca - para o nível baixo que o Nilo tem no Inverno e a subida que as chuvas a sul the provocam no Verão(16). Seja como for, afirma Heliodoro (9. 22. 5), certo é que "é o Nilo que marca as estações; no verão com as cheias, no Outono com o decréscimo das águas, na Primavera com as flores que faz nascer e com a postura dos crocodilos"(17).

De acordo com Heródoto, a surpresa que os Gregos sentiam pelas cheias do Nilo tinha réplica na atenção que também os Egípcios Ihes dedicavam. De há muito eles haviam igualmente percebido que a irrigação das suas terras se não devia às chuvas, como acontecia na Grécia; e, sem se interpelarem sobre as suas razões científicas mais profundas, consideravam-se mais seguros pela regularidade com que o rio garantia a fertilidade dos solos, enquanto as chuvas, mais precárias, ameaçavam de seca (2. 13). Fazendo-se eco de uma longa tradição, Aquiles Tácio pode sintetizar (4. 12. 1): "O grande Nilo é tudo para os Egípcios: rio, terra, mar e lago». Para prosseguir com toda a actividade que fervilha em sua volta, numa estranha fusão de terra e água. Este será o único espaço do mundo onde «barco e alvião, remo e arado, leme e foice" convivem em harmonia. "Onde antes se navegou, agora planta-se, e o campo que se planta é o mar que se cultiva". E não é só no delta, onde esta fusão parece mais indissociável, que ela ocorre. O lago Meris ${ }^{(18)}$, por exemplo (cf. Hdt. 2. 149-150), assemelha-se a um mar, pela cor (Strab. 17. 1. 35), enquanto o oásis de Ámon apresenta características marítimas, como conchas e barcos (Strab. 1. 3. 4).

Mas foi muito mais longe, segundo Heródoto 2. 11, a generosidade do rio. De acordo com uma teoria decerto proveniente da lónia, o próprio solo egípcio teria sido formado pelos sedimentos que o Nilo transportava da Etiópia, num processo de acumulação progressiva. 
A demonstrá-lo estão os sedimentos da costa (2. 5. 2) e a diferença evidente entre o tipo de solo egípcio, "negro e friável», e o dos territórios da vizinhança (2. 12. 2), avermelhados e arenosos, da Líbia e da Arábia. Há ainda a acrescentar às provas físicas os depoimentos locais, de ordem teológica, fornecidos pelos sacerdotes; segundo eles, um milénio antes, bastava que o rio ultrapassasse oito cúbitos de altura para cobrir o Egipto; enquanto no tempo de Heródoto o seu nível precisava de atingir os quinze cúbitos para obter o mesmo efeito, o que provava que, pela acumulação de sedimentos entretanto produzida, a altura do solo tinha aumentado (2. 13. 2, 2. 14. 1). Pode, em consequência, Heródoto deduzir que a manter-se o mesmo ritmo de sedimentação a seca se tornaria no futuro inevitável ${ }^{(19)}$.

Com esses sedimentos o Nilo preencheu um enorme fosso que ligava África e Ásia, semelhante ao golfo arábico, ou seja, o mar Vermelho. Por analogia, imagina Heródoto, o Nilo, se para lá se desviasse o seu curso, seria capaz, em 10.000 anos, de atulhar também o vizinho golfo da Arábia. O que significa que uma força natural, com a pujança e a dinâmica do Nilo, é capaz de alterar a configuração da ordem e a proporção terra / água universal ${ }^{(20)}$.

A cumplicidade existente entre o Nilo e o território que ele cruza faz do Egipto uma dádiva das suas águas. Já a Odisseia 14. 258 parece confundir país e curso de água, dando ao rio a designação de "Egipto". Esta ideia aparece totalmente consolidada quando, em finais do séc. VI e inícios do V, Hecateu de Mileto se refere ao Egipto como "dádiva do Nilo" (FGrHist $1 F$ 310), ideia que o próprio Heródoto, decerto inspirado no geógrafo de Mileto, repete (2. 5. 1) ${ }^{(21)}$. A credenciar esta mesma circunstância com o aval divino, o autor de Histórias (2. 18. 3) transcreve uma resposta do deus Âmon a propósito de uma dúvida colocada quanto aos limites do Egipto: «Egipto», declarou o deus, "é o território que o Nilo alaga com as suas inundações, e Egípcios são os que habitam para cá da cidade de Elefantina e bebem a água do rio". Tirando ilações das palavras do oráculo, Heródoto pode concluir (2. 19. 1): "Ora o Nilo, aquando das cheias, cobre não apenas o delta, mas também a parte do território dita líbica e a arábica, até uma distância de cerca de dois dias de marcha para cada lado" "(22). Dentro da mesma linha, Ésquilo (Pers. 311) refere genericamente os Egípcios como "os vizinhos da corrente do Nilo"; enquanto a Helena euripidiana, exilada no Egipto (Hel. 670-671), se diz "levada para o Nilo".

Além de definir fronteiras, o Nilo, como espinha dorsal do Egipto, estabelece-lhe também a dimensão, medida em dias de navegação 
(2. 8-9); o seu curso segue um longo vale, ora mais estreito ora mais largo, ladeado por montes, arábicos a nascente e líbicos a poente (2. $8-9,2$. 11. 2). O Nilo tornou-se, pelo percurso que cumpre ao longo de todo o Egipto, a maior rede viária do país. Por ele circulavam as mercadorias, em barcos que Heródoto descreve em pormenor, sendo a navegação condicionada pelo próprio sentido: para sul só possível com o impulso do vento; para norte, em direcção ao delta, facilitada pela corrente (2. 96. 3) ${ }^{(23)}$. Em tempo de cheias, a navegação não se fazia, naturalmente, seguindo o curso do rio, dado que, com a extensão das águas, se abriam novas rotas «pela planície» $(2.97,1$; D. S. 1. 36. 2). O terreno torna-se então um mar, uma espécie de Egeu, onde só as cidades, construídas nas zonas mais elevadas, emergem como se fossem ilhas ${ }^{(24)}$ (cf. D. S. 1. 36. 8) e, em conformidade, as populações locais convertem-se em "navegadores dos pântanos» ( $€ \lambda \in$ เоßа́таı, A. Pers. 39-40). Não quererá a informação de Heródoto sobre a navegação "na planície» dizer que os barcos cruzavam os campos, mas que seguiam os canais de irrigação que, com as cheias, se tornavam navegáveis. De facto, para alargar a amplitude da irrigação, o Egipto foi progressivamente dispondo de uma rede de canais que levavam, durante $o$ ano inteiro, a água, e as mercadorias que por ela circulavam, até às populações mais afastadas do rio (2. 108. 3-4). A construção desta rede hidrográfica significou a opção por uma estratégia de circulação, na medida em que dificultou o tráfego com carros e cavalos. Por ela circulavam, entre outras mercadorias, os materiais destinados à construção dos enormes monumentos que caracterizam o Egipto (2. 108. 2; D. S. 1. 56-57), que o historiador associa em particular com a política "faraónica» de Sesostris. Um desses canais, pela sua importância referido com particular insistência (2. 158, 3. 42; Strab. 17. 1. 25), é o que ligava o Nilo ao mar VermeIho; construído pelo faraó Neco com grande aparato de meios, tinha por objectivo facilitar o comércio externo e assegurar à coroa egípcia o domínio do Mediterrâneo e do golfo arábico; juntamente com a armada que logo se mandou construir (2. 159. 1), interpunha uma barreira defensiva contra a ameaça do império caldeu e fazia do Egipto uma potência naval.

Se os Egípcios se mostraram capazes de se adaptar às condições que as cheias do Nilo Ihes impunham e de estender, por meio de canais, a vantagem a auferir das suas águas o mais longe possível, foram também capazes de intervir sobre o próprio curso em nome de outros objectivos. É disso exemplo a obra do desvio do leito 
do rio, segundo Heródoto empreendida pelo faraó Min (c. 3200 a. C.), o primeiro a reinar no Egipto (2. 99. 2-4); por um processo de terraplanagem, obteve um terreno seco para construir a cidade de Mênfis ${ }^{(25)}$. Essa barreira com que deteve as águas manteve-se, a partir de então, sob vigilância apertada e reparação constante, de modo a impedir que, por ruptura, Mênfis submergisse. Ao mesmo tempo, as águas do Nilo foram reencaminhadas noutro sentido e puderam, depois de escavado o terreno em volta da cidade, constituir um lago. Sobre a força do Nilo, o talento humano obtinha conquistas engenhosas. Séculos mais tarde (Hdt. 2. 100. 2-3), a rainha Nitócris (provavelmente no final da VI dinastia, c. 2065 a. C. $)^{(26)}$ é associada na ficção com as potencialidades do rio, desta vez usadas por motivos pessoais de vingança ${ }^{(27)}$. No desejo de punir os Egípcios que the tinham assassinado o irmão - a que ela própria sucedeu no trono -, a rainha serviu-se das águas para forjar um dolo. Empreendeu uma obra - a construção de uma grande sala subterrânea, com ligação directa ao Nilo - e, na cerimónia de inauguração onde estavam presentes os regicidas, fez irromper as águas do rio. Uma velha história de vingança feminina adaptava-se às condições culturais e geográficas do Egipto.

Sobre as nascentes do Nilo acumulam-se as dúvidas. Heródoto (2. 28. 1, 2. 29. 1) salienta a falta de informação que existe sobre esse território. Apesar disso, as Histórias dedicam às nascentes do Nilo um amplo tratamento (2. 28-34). Ele mesmo viajou até Elefantina (2. 29. 1), onde procurou recolher informações sobre o que se seguia, a sul. Não the mereceu confiança o depoimento que obteve de um escriba do templo de Atena em Sais, o único informador disponível; segundo essa fonte, as nascentes do Nilo estariam situadas justamente entre Siene (Assuão), na Tebaida, e Elefantina, nos montes Crofe e Mofe ${ }^{(28)}$. Vários pormenores sobre as características do Nilo nesse ponto do seu curso atraíam a atenção e justificavam a versão obtida por Heródoto. Em primeiro lugar, impressionava a profundidade que as águas do Nilo aí apresentavam, a sugerir que as fontes do rio se situassem no subsolo. Essa mesma característica estimulou o rei Psamético I (séc. VII a. C.) a procurar medir a altura do leito, o que se tornou impossível com uma simples corda, devido aos refluxos e à força da corrente ${ }^{(29)}$. Foram certamente também os mesmos redemoinhos que sugeriram a repartição das águas, à nascença, em dois sentidos opostos, um que se dirigia para o Egipto, a norte, e outro para a Etiópia, a sul. Esta versão provinha decerto do tempo em que os Egípcios desconheciam o curso do Nilo a sul da primeira catarata ${ }^{(30)}$. 
Das dificuldades de acesso dá Heródoto testemunho pela forma como se procedia à navegação; era preciso amarrar o barco a ambas as margens, sob pena de não resistir à força da corrente (2. 29. 2; D. S. 1. 32. 1-6). Vencidos, na versão das Histórias, doze dias de percurso por um leito sinuoso, acedia-se «a uma planície aberta, onde o Nilo corre em volta de uma ilha chamada Tacompso»(31). Esta é o ponto fronteiriço entre Egipto e Etiópia (que em Heródoto designa toda a zona a sul de Assuão), entre quem o território da ilha se repartia ${ }^{(32)}$. A caminho da segunda catarata, os escolhos no leito do rio eram de tal ordem que impediam a navegação. Esse é um troço do percurso que tinha de ser vencido a pé, em 40 dias de marcha (mais de 1000 $\mathrm{km}$ ), ao longo da margem, por um território de beduínos nómadas ${ }^{(33)}$. Depois de uma nova navegação de mais 12 dias, eis que o viajante atinge enfim Méroe, a capital da Etiópia ${ }^{(34)}$, pela primeira vez, em textos gregos, aqui referida. Ultrapassada esta cidade, seguia-se um longo trajecto, que, em dias (56 no total), Heródoto equilibra com o que separava Elefantina de Méroe, pelo território "dos desertores", forças egípcias que constituíam a guarnição defensiva do Egipto a sul e que debandaram a juntar-se ao inimigo etíope, no tempo de Psamético I (2. 30. 2-5) ${ }^{(35)}$. Logo, para além do percurso egípcio, o Nilo prosseguia por uma distância correspondente a quatro meses de navegação (2. 31). Enfim, o território que se segue, pela sua natureza desértica e escaldante, parecia inacessível. Só um relato vago de povos líbios, os Nasamones ${ }^{(36)}$, deu conta de uma aventura empreendida por exploradores africanos, segundo os quais as nascentes do Nilo se situavam a sudoeste, num imenso pântano a ocidente do deserto líbio, do Sahara (2. 32-33), em território de pigmeus (cf. II. 3. 3-7; Hdt. 4. 43. 3-5; Arist. HA 597a); aí testemunharam a existência de um grande rio pejado de crocodilos, que identificaram com o curso etíope do Nilo (muito provavelmente tratava-se do Niger, mas a existência de crocodilos, muito associados ao Nilo, sustentou a confusão) ${ }^{(37)}$. Por todas estas dificuldades de acesso e verificação, o assunto das nascentes do Nilo é, para a metodologia de Heródoto, inacessível (2. 34. 1): “É impossível fazer um relato das nascentes do Nilo, porque a Líbia, que ele cruza, é desabitada e deserta. Sobre o seu curso fiz a descrição possível, até onde a investigação o permite». A própria obscuridade destas franjas do mundo conhecido desafiou a imaginação dos poetas. Assim Prometeu, em Ésquilo, ao profetizar a lo o seu destino, localiza a sua rota de sofrimentos nesses extremos (Pr. 807-814): "Chegarás então a uma terra distante, de um povo negro ${ }^{(38)}$, que vive 
próximo das águas do sol, junto ao rio Etíope. Segue-lhe o curso até atingires a "Descida", aquele ponto em que, das alturas do monte Biblos, o Nilo projecta as suas águas santas e salubres. É ele que te vai conduzir ao país em triângulo".

Da importância do curso etíope do Nilo, certamente com o passar dos séculos mais familiar aos Gregos, fala Heliodoro nas suas Etiópicas ${ }^{(39)}$. Perante um auditório de Egípcios, Histaspes, o rei etíope, personagem do seu romance, defende as maravilhas do Nilo - plantas, flores e animais de que o rio é a dádiva - como um milagre etíope. É de lá que tudo aquilo que os Egípcios têm por sagrado provém, o que transforma a Etiópia na «mãe dos seus deuses" ( 9 . 22. 7). Centrando a sua atenção sobre Méroe, Heliodoro (10. 5. 1-2) retoma as informações de historiadores e de geógrafos (D. S. 1. 33; Strab. 17. 2. 2). Situa-a numa ilha triangular, rodeada de rios, o Nilo e dois dos seus braços, o Astaborras e o Asasobas. Não poupa, ao seu desenho, fantasia. Imagina-a enorme, "semelhante a um continente", e povoada de seres e de produtos de uma dimensão em geral desmesurada; se são enormes os animais que Ihe são próprios, sobretudo os elefantes, enormes são também as árvores e os frutos que produzem, em particular as tâmaras "grandes e suculentas"; as searas, por sua vez, lá atingiam a altura de um homem montado a cavalo ou mesmo sobre um camelo; e os canaviais permitiam construir, com cada cana, duas canoas (10. 4. 6) ${ }^{(40)}$. Esta era a visão fantástica de um mundo remoto a tocar a utopia ${ }^{(41)}$.

O carácter cosmopolita do romance grego, como um género que espelha a experiência mediterrânica em época helenística, justifica a importância que o Egipto ganhou como etapa das aventuras vividas pelo par protagonista da novela de amor. A verdade é que dos cinco exemplares conservados, três contextualizam no Egipto alguns dos seus episódios. São, por isso, inevitavelmente, o receptáculo de toda uma tradição literária focada no Nilo, ampliada pela cada vez maior acessibilidade do seu território; mesmo se ao serviço da ficção e inspirada em traços convencionais, a imagem que dão do Egipto e do seu rio é digna de atenção. Da região da Tebaida, Heliodoro (8. 14. $2-3,8.15 .1,6)$ recorda, com algum realismo, o calor sufocante, que convidava os viajantes a preferir a noite e a evitar horas de maior sol; vencidos os ardores do princípio da tarde, com o ocaso uma brisa refrescava um pouco o ambiente. Em traços gerais, desenha o curso do rio, com as suas línguas de terra, propícias à existência de pastos e acolhedoras para o gado. Uma pincelada local é trazida pela refe- 
rência às árvores da Pérsia, aos sicómoros e a outras espécies odoríferas que dão às margens do Nilo uma sombra protectora (cf. Teofrasto, História das plantas 4. 2. 1, que confirma a vulgaridade desse tipo de flora no Egipto e de que Heliodoro se poderia ter inspirado), bem como aos seus conhecidos canaviais (8. 16. 1).

É no romance que podemos colher o eco de algumas tradições associadas com o Nilo, desde logo as festividades de que a região do Alto Egipto era cenário. Não causa qualquer surpresa que as potencialidades superiores do rio egípcio tivessem feito dele uma divindade venerada em todo o país. Heliodoro (9. 9. 3-5) afirma-o com veemência: "Do seu ponto de vista o Nilo é um deus e o mais poderoso de todos"; retoma ainda a tradição que faz do Egipto o fruto de uma união feliz "entre o húmido e o seco». Mas esta explicação objectiva encontra no ritual uma outra expressão reservada aos seus fiéis. Para esse, Ísis é a Terra e Osíris o Nilo, designações divinas para coisas terrenas ${ }^{(42)}$. Curiosamente Heliodoro prossegue valorizando o secretismo sobre os fenómenos naturais como um estímulo à sua divinização (9. 9. 5): "Os Egípcios conhecedores das ciências da natureza e de questões teológicas evitam revelar aos profanos, creio eu, o significado destas histórias. A esses contentam-se em dar-lhes uma instrução sumária, em tom mítico; aos iniciados propriamente ditos reservam, para as dar num santuário iluminado de tochas, revelações mais claras". Heliodoro descreve ainda os Neiloa (9. 9. 2), que considera a mais importante das festas egípcias; "celebram-se no solstício de verão, no início das cheias, e nenhumas outras movimentam tão grande empenho por parte do povo" (cf. D. S. 1. 36. 10). O romance localiza-as em Siene e anima-as com sacrifícios e cerimónias em que toda a população participava $(9.10 .2)^{(43)}$. Heródoto já refere diversos rituais com que o Nilo era homenageado ou a sacralização dos episódios de que era cenário. Assim, por exemplo, qualquer ser humano, vítima do rio ou de algum dos animais perigosos que o povoam, como os crocodilos, se tornava sagrado; o seu cadáver era então objecto de rituais próprios e apenas manipulado pelas mãos de sacerdotes, «por o considerarem mais do que um simples despojo humano" (2. 90. 1-2) $)^{(44)}$. A divinização do Nilo permitiu aos autores de romance tornarem-no responsável por milagres de salvação em que o género abunda. Assim Aquiles Tácio (4. 2), adaptando o conhecido episódio da salvação de Creso das chamas da pira a que Ciro o havia condenado, tal como Heródoto o descreve no Livro I das Histórias, substitui o deus de Delfos pelo Nilo. Condenado também às chamas de uma pira, cons- 
truída sobre um precipício junto ao curso do Nilo, Habrócomes, o jovem protagonista das Efesíacas, apela ao rio como "o deus de todos os deuses, o mais misericordioso para com os homens" (4. 2. 4). Com uma inundação - não com um aguaceiro como no caso do rei da Lídia -, o Nilo salva-o e transporta-o, incólume, nas suas águas. Num sinal de resposta ao apelo do condenado, "o Nilo começou a ficar revolto, uma bátega de água abateu-se sobre a pira e apagou as chamas" (4. 2. 9).

Uma palavra é devida ao exotismo da fauna que povoava o vale do Nilo, fascinante para a imaginação de um grego. Sem dúvida que o animal principalmente associado ao rio era o crocodilo, cujas descrições feitas por Heródoto (2. 68-70) - sobre a configuração e hábitos da espécie, o seu habitat, o carácter sacro e as actividades com ele relacionadas - ficaram célebres. Por isso, o crocodilo regressa como logótipo do Egipto no romance. Heliodoro (6. 1. 2) interpreta, de acordo com critérios de superstição, o encontro com um crocodilo, que se atravessa muito significativamente diante de um grupo de viajantes da direita para a esquerda, de onde Calásiris, um sacerdote de Mênfis personagem do romance, "percebeu o sinal de um obstáculo que iria atravessar-Ihes o caminho". Aquiles Tácio (4.19) regressa à tradição de Heródoto com uma longa descrição do crocodilo(45). O hipopótamo, etimologicamente "o cavalo do rio", é uma outra criatura a merecer a atenção de geógrafos e etnólogos (Hdt. 2. 71; Arist. HA 502 10-15; Aq. Tac. 4. 2). Acrescentem-se espécies mais ou menos fantásticas como a fénix, um exemplo de comportamento inteligente e piedoso. Heródoto (2. 73) e Aquiles Tácio (3. 25) falam de como a fénix, migrada da Etiópia para o Egipto, sepulta o pai num invólucro de mirra e voa de seguida para Heliópolis, onde promove uma espécie de rito funerário. Por fim, no grupo dos animais de referência, o flamingo do Nilo (Heliod. 6. 3. 2) é referido como uma espécie de "lembrança» que pode cativar a atenção da mulher amada.

De todas as regiões que o Nilo irriga nenhuma, porém - dada a própria acessibilidade e a permanência de colónias ${ }^{(46)}-$, mereceu aos Gregos tanta atenção como o delta. Para alguns, como parece ter sido o caso de $\mathrm{Hecateu}^{(47)}$, o Egipto confinava-se apenas ao delta (Hdt. 2. 15. 1) e não passava abaixo da cidade de Cercasoro(48), onde o Nilo se reparte entre os braços de Pelúsio e de Canopo; todo o demais território, incluíam-no na Líbia e na Arábia. A ser assim, comenta Heródoto, "no passado os Egípcios não teriam território", o que é inaceitável para quem considera este um dos povos mais antigos à superfície 
da terra (2. 15. 2, 2. 43. 4, 2. 144. 2)(49). Os navegantes gregos sabiam com clareza que, até uma certa distância da costa egípcia, o mar apresentava um fundo lodoso, que estava relacionado com os sedimentos do Nilo (2. 5). Heródoto afirma até que a linha de costa egípcia se projecta para além da das regiões vizinhas, em função desses mesmos depósitos (2. 12). Além do testemunho geofísico, o autor de Histórias invoca a opinião dos sacerdotes para reconhecer que boa parte do território foi ganha ao mar por interferência do Nilo (2. 10), a partir do que antes seria um golfo. Logo, como bem afirma Vannicelli 2001: 237, "viajar rio acima a partir da costa marítima é fazer um percurso até à velha história do Egipto".

A configuração e limites do delta são matéria de constante referência literária. Em 2. 17. 2-3, Heródoto, fazendo-se porta-voz do pensamento grego sobre a matéria, descreve o percurso do Nilo, das cataratas até ao mar, como uma divisória central do Egipto. A partir da cidade de Cercasoro, divide-se em três ramos: para leste a chamada boca de Pelúsio, para ocidente a Canópica, e uma terceira que divide ao meio o espaço definido pelas outras duas, que é a Sebenítica (2. 17. 4-5). Esta última, por sua vez, subdivide-se em duas menores, a Saítica e a Mendésia ${ }^{(50)}$. A tragédia grega envolve em aroma poético esta realidade geográfica. Ésquilo (Supp. 4-5) fala "das embocaduras

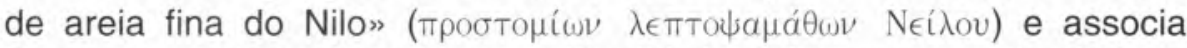
Canopo, a cidade do extremo ocidental do delta, com o mito de lo e de seu filho Epafo, nascido no Egipto (Pr. 846-852, Supp. 311-314). Eurípides (Ba. 406-408) celebra, com exagero poético, as 100 bocas do Nilo. Outras referências míticas aparecem associadas a este espaço. Situada por Heródoto no extremo ocidental, ao que parece erradamente, estava a "chamada torre de Perseu»(51) (2. 15. 1; cf. E. Hel. 768-769), lugar do salvamento de Andrómeda de um monstro marinho pelo jovem herói (tema a que Eurípides dedicou uma tragédia famosa, Andrómeda, em 412 a. C.).

Incontornável é também a passagem mítica de Helena e Menelau pelo Egipto. Em fuga com Páris - na versão de Heródoto - Helena teria aportado na boca Canópica, no extremo ocidental, cujo nome aliás Ihe foi dado de Canopo, o piloto de Menelau, que lá perdeu a vida $^{(52)}$. Na costa situava-se um santuário de Héracles, residência do sacerdote guardião da boca do Nilo (2. 113), que Heródoto diz existir ainda no seu tempo. Foi a esse sacerdote, segundo a lenda, que coube denunciar o rapto, cometido pelo troiano, ao faraó Proteu, então residente em Mênfis (2. 114-115), onde os fugitivos compareceram. No 
regresso da guerra, Menelau navegou por sua vez até Mênfis (2. 119) para recuperar Helena e os tesouros que a acompanhavam, além de ter recebido do faraó generosas oferendas.

Associados a diversas cidades do delta há costumes e práticas que Heródoto descreve com algum pormenor, pelo que tinham de exótico para um público grego (2. 35. 2): em função de um clima diferente e da natureza tão peculiar do seu rio, os costumes do povo só podiam ser igualmente distintos. Assim, por exemplo, os funerais das vacas sagradas, cujo cadáver era lançado ao rio para, depois de putrefacto, ser recuperado numa região entre as bocas canópica e sebenítica, a ilha Prosopítide (Hdt. 2. 165), e sepultado (2. 41) ${ }^{(53)}$. Entre as festas do delta (Hdt. 2. 59) ${ }^{(54)}$ sobressaíam as de Ísis em Busiris, cidade da margem esquerda da boca sebenítica, dimensionadas pela importância do santuário aí existente (2. 59, 61). Em Bubástis, na boca de Pelúsio (Hdt. 2. 59. 1, 2. 60), celebrava-se Ártemis ${ }^{(55)}$, com grande aparato; homens e mulheres, reunidos em embarcações, navegavam por entre cantos e danças, numa peregrinação que tocava todas as cidades ao longo do rio, até regressar ao ponto de partida, onde sacrifícios e muito vinho animavam uma enorme multidão. Em Saís (2. 62), celebrava-se Neit (Atena) com uma vigília nocturna, à luz das lamparinas, a conhecida "festa das luminárias". Em Heliópolis celebrava-se o Sol, em Buto, na boca sebenítica, Latona e, por fim, em Papremis, provavelmente no Nordeste egípcio, o deus Ares (Hdt. 2. 63).

Naturalmente que a sedimentação de novos terrenos no delta exerceu sobre as populações um grande efeito atractivo. De resto a fertilidade deste tipo de solos compete com qualquer outra no mundo, mesmo com a que conheciam os Egípcios do Médio e Alto Egipto (Hdt. 2. 14. 2). Heródoto faz da agricultura no delta um processo quase autónomo, próximo de um paraíso utópico. Esquecendo o ardor habitual dessas tarefas, valoriza a colaboração do rio; não se torna necessário abrir sulcos ou arar a terra; basta aguardar que o Nilo regue os campos (autómatos), lançar a semente à terra e deixar que os próprios animais, postos à solta, as enterrem com as patas ${ }^{(56)}$. Heródoto (2. 13. 2) reconhece no entanto que, em compensação, se o leito do Nilo continuar a subir por acumulação de sedimentos, serão também as populações do delta a sofrer mais intensamente os efeitos das secas.

$\mathrm{O}$ delta do Nilo passou, no romance, em finais do período helenístico e no imperial, a ser terra de grande perigo para quem a percorria, em função da presença de assaltantes mais ou menos organizados, conhecidos por Boukółol, "os Boieiros" (Heliod. 1. 6. 1, 2. 24. 
1; Aq. Tac. 3. 9. 2) ou Пoцféveৎ "os Pastores" (Aq. Tac. 3. 12. 2) $)^{(57)}$. Esta é uma realidade desconhecida de Heródoto (que, no entanto, refere os habitantes do delta como distintos dos restantes Egícpios, pela sua história e costumes), embora Tucídides (1. 110. 2) fale da agressividade das gentes do delta; tornou-se, no entanto, comum em época romana ${ }^{(58)}$. Heliodoro (1. 1. 1) descreve-os como "bandos de homens armados como assaltantes, emboscados nos montes que se estendem ao longo da embocadura do Nilo" e situa-os na boca de Hércules, ou seja, em Canopo, na zona que confina com o deserto líbio (cf. Heliod. 5. 27. 7-8). Embora a geografia do romance não seja rigorosa, nos seus traços largos respeita a realidade: para aceder aos esconderijos, nos montes líbios, "os piratas" do Nilo (1. 3. 1) "seguem a margem do rio, com o mar à direita, e dirigem-se em frente até ao sopé da montanha. (...) Do outro lado havia um lago" (1. 5. 1). Entretanto a zona baixa, o vale do rio, que os Egípcios designam por «terra de pastagens" (Heliod. 1. 5. 2), torna-se inabitável em tempo de cheias, formando uma espécie de lago profundo, de margens pantanosas ${ }^{(59)}$. Por sua vez Aquiles Tácio (3. 5. 5-6) situa-os no extremo oposto do delta, em Pelúsio ${ }^{(60)}$. Os dois romancistas aproximam-se porém no que se refere ao retrato destes homens, na descrição de Aquiles Tácio (3. 9. 2): Selvagens e de aspecto assustador; altos, de pele negra, de cabeça rapada, pés ligeiros, estatura atarracada, armados de arco e flecha, que falavam uma língua bárbara. Heliodoro é particularmente insistente na dificuldade de comunicação que a diferença linguística impunha relativamente aos Gregos que por lá naufragassem (1. 3. 1, 1. 4. 1-2, 1. 7. 3, 1. 19. 3, 1. 21. 3), além da cor negra e aspecto asqueroso (1. 3. 1) ${ }^{(61)}$. Mais adiante, o mesmo Aquiles Tácio (3. 12. 1) descreve-os, pelo contrário, como de longos cabelos, hirsutos, e particularmente como bons cavaleiros, usando as montadas em pêlo, sem sela nem arreios (cf. Heliod. 1. 3. 4, 1. 4. 2). Viver entre os Pastores, para um estranho, podia equivaler a tomar- Ihes o aspecto, deixando crescer os cabelos até aos sobrolhos e a tocar os ombros (Heliod. 2. 20. 5, 2. 21. 2).

Estabelecidos em comunidades marginais ${ }^{(62)}$, são descritos na novela como grupos organizados em torno de um chefe, o seu rei (Heliod. 1. 7. 1) ${ }^{(63)}$, que vivem em verdadeiras "cidades" (Heliod. 1. 5. $3)^{(64)}$. O estádio de civilização em que estão é atrasado, em função dos restantes Egípcios. Alojam-se em cabanas (Heliod. 1. 5. 3, 1. 30. 2, 2. 3. 2; D. S. 1. 43. 4; Aq. Tac. 4. 12. 1), implantam-nas em terrenos enxutos, ou "no meio de um lago", servindo-se das condições do 
terreno como de uma defesa natural ${ }^{(65)}$, aproveitando a conivência e a protecção dos canaviais (Heliod. 1. 6. 1); há-os também que vivem em embarcações, que Ihes permitem uma vida nómada (A. Pers. 39-40 ; Heliod. 1. 5. 3, 1. 31. 2) ${ }^{(66)}$.

Na própria forma de lutar, como a imagina Aquiles Tácio, está evidente a adaptação às condições do terreno. Embora mal armados e habituados a lutar com torrões arrancados ao solo (Aq. Tac. 3. 13. 2-3), os Pastores eram hábeis em recorrer às próprias águas do rio (Aq. Tac. 4. 14); abriam os diques e permitiam que a água invadisse o campo de luta, de modo a diluir as fronteiras entre pântano e terra firme; por força das condições inauditas do terreno, a confusão entre infantaria e marinha era total ${ }^{(67)}$.

Já Heródoto (2. 92) tinha definido, entre os costumes comuns a todos os Egípcios, alguns próprios dos habitantes do delta. Essas diferenças são estipuladas mais uma vez pelo rio e pelo ambiente ecológico que ele proporciona. Algumas plantas comuns nas margens do Nilo, como o lotus (cf. Heliod. 10. 3. 2, onde a celebração de uma vitória em combate passa pela coroação com o lótus egípcio), têm no delta uma função alimentar, fazendo-se pão das suas sementes (Hdt. 2. 92). Comestível é também o fruto de outras plantas do tipo "rosa", que nascem no rio, ou até os papiros tenros, passíveis de múltiplas aplicações (Hdt. 2. 37, 38, 96, 5. 58, 7. 25, 34, 36, 8. 29); do rícino fazem um óleo alimentar (2. 94). Mas sobretudo relevante na alimentação dos habitantes do delta é o peixe. A colheita das espécies, diz Heródoto, torna-se particularmente abundante em tempo de cheias, quando os espaços ocos do terreno próximos do caudal do rio ${ }^{(68)}$ se enchem de peixes. Tudo parece indicar que, em consequência deste produto em que o delta era fértil, havia em toda a costa egípcia salga de peixe (Hdt. 2. 113. 1; D. S. 1. 36. 1). Heliodoro (1. 5. 4) inclui o peixe seco ao sol na dieta habitual da região.

Esta zona inóspita era, segundo Estrabão (17. 1. 18), desprovida de portos e mesmo o da ilha de Faro estava sob o controle dos Pastores. Mais um motivo para tornar frequente a pilhagem dos náufragos. Com estas características, o delta do Nilo tornou-se um local atraente para os romancistas localizarem episódios aventurosos. Heliodoro situa nesse território o primeiro capítulo da sua novela, depois de travada, entre dois grupos rivais de salteadores, uma batalha pelo saque de um navio encalhado (1. 3-7, 1. 22. 5); Xenofonte, nas Efesíacas, faz do seu personagem Habrócomes um prisioneiro dos Pastores (3. 12. 2); em Aquiles Tácio, é uma parte significativa dos Livros 3 e 4 
que decorre nesse local; aí Leucipe, a protagonista, é capturada pelos piratas e vendida num mercado de escravos de Alexandria, uma ágora agitada e cosmopolita (3. 9. 1, 3. 11. 1). Naturalmente esta preferência tem a ver com o próprio convencionalismo da novela, que multiplica naufrágios, raptos, combates, que poderiam ter nas costas do Egipto e seus habitantes agentes ideais. Whitmarsh 2008: 118 lembra que, ao factor tradicional se associava a realidade, experimentada por comerciantes que circulavam na região de Alexandria.

Feito este percurso por uma dezena e meia de séculos através da literatura grega, podemos concluir com a projecção que o Egipto e o seu rio tiveram na atenção de poetas e prosadores ao longo dos séculos. Quer sob uma forma idealizada, quer numa versão que pretende espelhar a especulação "científica» em vigor, a verdade é que o Nilo não deixou nunca de estimular o espírito e imaginação dos seus vizinhos Helenos.

\section{Notas}

(1) Aquiles Tácio 4. 12. 2 comenta esta regularidade em termos expressivos: "O Nilo não mente, é um rio que cumpre os seus prazos, que respeita os horários e regula o caudal das suas águas, um rio que não quer ser apanhado em atrasos». As traduções de Aquiles Tácio são citadas de A. PENA, Aquiles Tácio. Os amores de Leucipe e Clitofonte, Lisboa, Cosmos, 2005.

(2) O único que se lhe aproxima em volume é o Istro (Danúbio), uma espécie de réplica do Nilo no hemisfério norte (4. 50).

(3) Heródoto 2. 12. 2-3 assinala o contraste entre o solo negro e friável do Egipto, arrastado da Etiópia pelo Nilo, e o de areia avermelhada da Líbia e da Arábia (vide infra). Aquiles Tácio 3. 13. 3 refere também o solo egípcio de assinalável dureza.

(4) Apesar de considerar que as regiões são muitas vezes identificadas pelo seu rio, Allan Euripides. Helen, Cambridge, University Press, 2008, 144 não deixa de reconhecer que esta é uma ocorrência única em Eurípides, em vez dos habituais "cidade / palácio / ilha..." a que alude nas aberturas das suas peças. A preferência pela menção do Nilo na Helena merece, por isso, registo.

(5) 2008: 201.

(6) Herodotus in context. Ethnography, science and the art of persuasion, Cambridge, University Press, 2000, 139.

(7) Heliodoro 2. 27. 1 retoma a mesma pergunta.

(8) Este calendário sugere que Heródoto se reporta ao Baixo Egipto. De facto, o Nilo alaga, à altura de Assuão, no início de Junho, e na zona do Cairo cerca de vinte dias mais tarde, ou seja, por volta de 22-23, quando ocorre o solstício de Verão.

(9) Sobre esta afirmação polémica de Heródoto, já que é sabido que há ventos no curso do Nilo (ele mesmo se refere aos ventos etésios (2. 20. 2) e às brisas fortes do Nilo (2. 96. 
3), vide BAXENDALE, J. W., "Herodotus and the missing Nile aûpat", Mnemosyne 47/4, 1994, 433-453. Outros testemunhos antigos (Arist. Probl. 945 20; Theophr. D.V. 5-6) falam dos ventos do Egipto; em Theophr. D. V. 25, no entanto, repete-se a mesma informação de Heródoto.

(10) Sobre estas diversas teorias, vide THOMAS (2000) 183-185.

(11) Heródoto é, aliás, muito depreciativo sobre esses sábios da lónia que tem no espírito e de quem diz (2. 20. 1) que são gente "que pretende arrogar-se fama de sábios".

(12) Há uma velha tradição, ainda que contestada por vários estudiosos, segundo a qual Tales teria visitado o Egipto (cf. BAXENDALE (1994) 445).

(13) Erodoto. Le Storie II, Milano, Lorenzo Valla, ${ }^{3} 1996,250$.

(14) D. S. 1. 37. 7 admite que esta fosse a versão difundida pelos sacerdotes egípcios. Muito provavelmente Hecateu, autor de uma Periodos Ges, "Viagem à volta da Terra", poderia estar também na mira crítica de Heródoto.

(15) Nos Metereologica 346b 22, atribuídos a Aristóteles, refere-se a evaporação existente sobre o Nilo, que pode provocar neblinas e nevoeiros. Ésquilo (Supp. 75) fala do Egipto como «terra de neblinas".

(16) Cf. Diógenes de Apolónia DK 64 $4^{\mathrm{a}}$ 18. Curiosamente Heliodoro (2. 27-28), como bom leitor de Heródoto, retoma as teorias aqui expostas, apoiando como mais viável a que o próprio historiador emite como sua. Aos argumentos de Heródoto acrescenta: "Eis por que a sua água é doce quando se bebe, porque vem do céu, e tão agradável ao tacto; nem é tão quente como na origem do seu curso, mas ainda tépida, por vir de uma região tórrida". Sobre a influência de Heródoto em Heliodoro, vide WHITMARSH, T., The Cambridge Companion to the Greek and Roman novel, Cambridge, University Press, 2008, 115. Heliodoro como que sacraliza o fenómeno das cheias, quando põe Calásiris a aprender-Ihes o segredo a partir dos livros sagrados, como se de um processo de iniciação se tratasse.

(17) E acrescenta uma estranha teoria de que, calculadas as suas letras segundo o respectivo valor $-v+\epsilon+l+\lambda+0+\varsigma=50+5+10+30+70+200=365-$, se totaliza os dias do ano.

(18) Este lago ocupava a depressão designada por El Fayum, justamente "o mar». Era um lago enorme, ligado ao Nilo por um canal, por onde a água entrava para alimentar o lago e, em certas épocas do ano, defluía de novo para o Nilo. Sobre o assunto vide HOW, W. W., WELLS, J., A Commentary on Herodotus, Oxford, University Press, 1991, 242.

(19) HOW, WELLS (1991) 166 assinalam o desconhecimento de Heródoto de que o leito do rio sobe em proporção com o aumento das margens.

(20) Vide ROMM, J., Herodotus, New Haven/London, Yale University Press, 1998, 87; CORCELLA, A., Erodoto e l'analogia, Palermo, 1984, 62-63, 81.

(21) Disso mesmo dá testemunho Arriano, Anab. 5. 6. 5: "Ambos os historiadores, Heródoto e Hecateu, designam de igual forma o Egipto como dádiva do Nilo".

(22) Há algum exagero nesta medida, que se se pode adequar ao delta, é inflaccionada para o vale do rio.

(23) Esta seria uma experiência testemunhada pelos inúmeros mercadores, que tinham das dificuldades da navegação no Nilo um conhecimento profundo.

(24) Heródoto 2. 111. 1 recorda uma cheia excepcional, em que o rio atingiu 18 cúbitos de altura (cerca de 8 metros) e produziu até ondulação por força dos ventos. 
(25) Esta versão, que Heródoto diz ter ouvido aos sacerdotes, parece infundada. LLOYD, FRASCHETTI ( ${ }^{31996)} 321$ tomam-na por uma lenda e adivinham-Ihe as razões: a ideia de que Min, o primeiro faraó, tinha fundado Mênfis, uma cidade realmente muito antiga; a atribuição a este monarca de um reino de prosperidade traduzido em projectos de construção e de irrigação; a noção de que o controle das águas do rio tinha sido, no Egipto, um problema de sempre. É portanto corrente que Heródoto associe os primórdios da realeza egípcia com a própria história geológica do país. Também o território, como que a viver a sua fase fundacional, não passava de um enorme pântano (2. 4. 3); vide VANNICELLI, P., "Herodotus' Egypt and Universal History", in N. Luraghi, ed., The Historian's craft in the age of Herodotus, Oxford, University Press, 2001, 236. Sobre a existência de um lago em volta de Mênfis, cf. Strab. 17. 1. 32; HOW, WELLS (1991) 216.

(26) Sobre as dúvidas suscitadas por esta personagem, vide HOW, WELLS (1991) 216-217.

(27) Entre os diversos testemunhos desta lenda, cf. Eratóstenes, FGrHist 610 F 1; Dio Cassio 62. 6, 79. 23; Juliano, Orationes 3. 129b.

(28) Esta teoria quanto à localização das nascentes do Nilo era vulgar já desde a época clássica (cf., e. g., PI. Tim. 22d; Strab. 17. 1. 52). Lloyd e Fraschetti ( ${ }^{31996)} 253$ corrigem a informação de Heródoto, situando os dois montes acima, ou seja, a sul de Elefantina; sem, no entanto, porem em dúvida a visita de Heródoto à "cidade do marfim". Por sua vez WAINRIGHT, C. A., "Herodotus II. 28 on the sources of the Nile", JHS 73, 1953, 104107, estranha as dúvidas suscitadas, na certeza de que era muito antigo o conhecimento do território a sul da primeira catarata. Entende assim que o sacerdote raciocinava na perspectiva do Nilo egípcio.

(29) ELMER, D. F., “Heliodoros's sources: intertextuality, paternity and the Nile river in the Aithiopika", TAPhA 138, 2008, 436, assinala que, além de Heródoto, Psamético é o único personagem das Histórias a promover uma investigação sobre o Nilo. Anunciava-se, com esta tentativa falhada, um exercício de controle do leito do rio que se tornou depois regular. Para o medir passou a usar-se o "Nilómetro", referido por Strab. 17. 1. 48, que D. S. 1. 36. 11 designou com a palavra Neiגođкотеíov, o "Nilóscopo". Heliodoro 9. 22. 3 descreve o sistema de medida do Nilo: em Assuão mostrava-se um poço, destinado a assegurar o processo, e semelhante a um outro existente em Mênfis. Construído em pedra, com uma escala de marcas gravada, comunicava com o Nilo pelo subsolo e registava o nível da água, permitindo a vigilância sobre a altura do rio. É provável que Heliodoro estivesse a usar a versão de Estrabão, ou que ambos utilizassem uma fonte comum.

(30) Séculos mais tarde Heliodoro (2. 29. 1) falava da opinião dos sacerdotes de Catadupo, uma cidade vizinha da primeira catarata e portanto da ilha de Filas, sobre as razões das cheias do Nilo, provocadas pelas chuvas que se precipitam nas montanhas etíopes. Sobre a importância literária desta investigação nas Etiópicas, vide ELMER (2008) 429-450.

(31) Há algum exagero no tempo de navegação previsto, porque a catarata terminava a cerca de $10 \mathrm{~km}$ a sul de Elefantina. Tacompso talvez seja identificável com a actual Djerar, a cerca de $115 \mathrm{~km}$ a sul de Elefantina.

(32) Heliodoro 9. 26. 2 fala das "fronteiras que a própria natureza estabeleceu, desde sempre, entre o Egipto e a Etiópia: as cataratas".

(33) Provavelmente é a este troço que Heliodoro 10. 1. 2 se refere quando fala do percurso para a Etiópia que se faz bordejando o rio; "ao chegar às cataratas (...) mudou de direcção e meteu para o interior".

(34) Méroe foi, durante séculos, a capital da Etiópia. Ficava a sul da quinta catarata. Foi no tempo dos Ptolemeus, não no da ocupação persa, que Méroe se tornou uma cidade próspera. 
(35) No período saítico, Elefantina era o extremo sul do Egipto e estava exposta aos ataques da Etiópia, então um reino poderoso. Heliodoro 8. 1.2 referia-se ainda a este episódio que parecia ganhar laivos de mito: "A cidade de Filas situa-se no Nilo, um pouco acima das cataratas pequenas, a cerca de 100 estádios de Siene e de Elefantina. Outrora ocupada e colonizada por exilados egípcios, passou a ser disputada pela Etiópia e pelo Egipto: uma reclamava-a, porque as cataratas marcam a fronteira com a Etiópia; o outro apelava a uma ocupação antiga por exilados vindos do Egipto, com o pretexto de que esta invasão pacífica lhe dava direitos sobre a cidade" (cf. Strab. 17. 1. 49-50); por isso, acrescenta Heliodoro 8. 1. 3, a ilha mudava de domínio com frequência, entre Etíopes e Egípcios.

(36) Chegado a Heródoto em quinta mão: primeiro contado a uns gregos de Cirene pelo rei dos Amónios, Etearco, que por sua vez o tinha ouvido a uns Nasamones, que o atribuiam a um grupo de exploradores. Sobre o desconhecimento desta região, cf. D. S. 1. 37. 5.

(37) ROMM (1998) 91-92, valoriza a simetria que Heródoto estabelece, na sua dedução perante o relato que lhe é feito, entre Europa e África, e entre o Nilo e o Istro (Danúbio). Exactamente sobre esta área desconhecida onde se situariam as nascentes do Nilo, Heródoto imagina-a semelhante à corrente do Danúbio, cujas fontes se situam "no lado oposto" (2. 34) ao delta do Nilo, ou seja, no hemisfério norte. Para Heródoto, comenta Romm, o Egipto era uma espécie de "território de pernas para o ar", de acordo com a ideia iónica de que Europa e África formavam duas metades opostas do globo. Cf. ainda CORCELLA (1984) 59.

(38) As Danaides (Supp. 70), a propósito do seu tom de pele, aplicam a si próprias o neo-

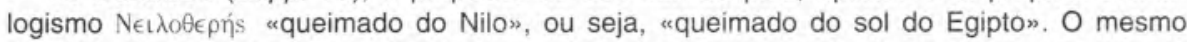
tom de pele é assimilado pelo mito em relação ao descendente de lo, o "negro" Epafo, nascido no Egipto (Pr. 850-852).

(39) Em geral o retrato da Etiópia produzido por Heliodoro é muito convencional e sobretudo anacrónico, sobrepondo a Etiópia do tempo de Heródoto com a contemporânea dos Ptolemeus. Ao tempo da ocupação persa (consumada por Cambises em 525 a. C.), um império etíope como ele o imagina não existia.

(40) Heródoto (2. 96. 1) fala das acácias como as árvores que fornecem a madeira para a construção dos barcos egipcios.

(41) Cf. WHITMARSH (2008) 116.

(42) Cf. Plut. Moralia 363 d. Mais adiante, em 9. 22. 5, o novelista identifica o rio com Horus, o Sol, "o alimentador de todo o Egipto: do Alto, o salvador, do Baixo, o pai e criador, que todos os anos traz um novo lodo (véav i $\lambda \dot{v} v$ ), de onde o nome grego do Nilo". Trata-se de uma identificação meramente fantasista. Heródoto (2. 59. 2, 2. 156. 5) sobrepõe Ísis a Deméter (2. 44. 2, 2. 144. 2) e Osíris a Dioniso; Aquiles Tácio (1. 6. 2) identifica o Nilo com «a sagrada ísis". A disparidade resultante destas diversas propostas mostra a controvérsia que a questão suscita.

(43) WINKLER, J. J., "The mendacity of Kalasiris in the Aithiopika" in S. Swain, ed., Oxford Readings in the Greek novel, Oxford, University Press, 1999, 344, sublinha o aproveitamento que Heliodoro faz, dentro da acção do seu romance, das cheias do Nilo e destas festas que as celebram. De certa forma, a viagem da heroína, Caricleia, para norte e o seu posterior regresso ao sul, reproduz, em paralelo, a subida e o retrocesso das águas do rio. Logo o destino da jovem aparece vinculado à própria natureza que a viu nascer.

(44) Sobre a interpretação da morte causada por um crocodilo, diversa em diferentes regiões do Egipto, cf. LLOYD, FRASCHETTI (31996) 311. 
(45) A diferença do tratamento do motivo pelos dois romancistas não passou despercebida aos comentadores do romance. WINKLER (1999) 294, por exemplo, sublinha que Aquiles Tácio segue a convenção da ecphrasis, fazendo da descrição minuciosa um elemento decorativo, enquanto Heliodoro, com um simples relance, enquadra o motivo do crocodilo na acção.

(46) Náucratis (cf. Strab. 17. 1. 18), por exemplo, na boca canópica, fundada no tempo de Psamético I, no início do século VII a. C., por Milésios é um exemplo central. Heródoto 2. 178-.179 informa de que Amásis veio a concentrar em Náucratis os Gregos inúmeros que viviam dispersos por todo o delta, o que deu à cidade um grande desenvolvimento comercial (sobre esta presença grega, cf. ainda 2. 154). Valerá a pena recordar, pela beleza do itinerário, a rota que Heródoto (2. 97. 2) traça de uma navegação no delta inundado, através de algumas cidades de referência: "Saindo de Náucratis para Mênfis, a navegação faz-se ao longo das próprias pirâmides. Mas esta não é a rota própria, mas antes aquela que segue a ponta do delta e a cidade de Cercasoro. Quem navegue do mar e de Canopo pela planície chegará a Náucratis, passando pela cidade de Antila e pela chamada Arcandro". Aquiles Tácio acrescentará às mais distintas cidades do delta uma descrição interessante da sua cidade natal, Alexandria (Livros 4 e 5).

(47) Cf. BROWN, T. S., "Herodotus speculates about Egypt", AJPh 86, 1965, 68.

(48) A pouco mais de uma dezena de quilómetros a norte do Cairo. Cf. Aq. Tac. 4. 11. 3.

(49) Era crença generalizada entre os Gregos que os Egípcios eram o povo mais antigo do mundo; cf. Hdt. 2. 15. 3; Arist. Pol. 1329b.

(50) ADRADOS, F., SCHRADER, C., Heródoto. Historia. Libros I-Il, Madrid, 1992, 298, assinalam um erro de Heródoto na designação da boca saítica, a que Estrabão (17. 1. 18) chama tanítica, por cruzar a cidade de Tânis (e não a de Saís). Mendésia vem do nome da cidade de Mendés. A sequência das bocas do Nilo, de este para oeste, seria portanto: pelúsica, saítica / tanítica, mendésia, bucólica, sebenítica, bolbinítica e canópica. Há, no entanto, sobre o número de bocas do Nilo uma disputa na Antiguidade; cf. D. S. 1. 33. 7 8; Strab. 17. 1. 18.

(51) Sobre o culto de Perseu no Egipto, cf. Hdt. 2. 91; D. S. 1. 24. 8; Strab. 17. 1. 18.

(52) É clara a tendência do mito para preferir como cenário o lado ocidental do delta. Se a passagem de Helena e Menelau pelo Egipto está referida no Canto IV da Odisseia, sobre a de Páris Alexandre em fuga com Helena este é o único testemunho.

(53) HOW, WELLS (1991) 186 relativizam esta informação de Heródoto, considerando que este não era um processo único de sepultar as vacas sagradas.

(54) Entre os capítulos 2. 59-63, Heródoto descreve seis festas famosas no Egipto, de âmbito nacional, ainda que com particularidades em diferentes regiões.

(55) Verdadeiramente a deusa egípcia Bastet, filha de Ré e deusa da alegria, representada com cabeça de gato. Talvez tenha sido exactamente a sua representação zoomórfica o motivo da aproximação que Heródoto faz com Ártemis.

(56) Sobre o emprego do gado na tarefa das sementeiras e as dúvidas que suscitou, vide D. S. 1. $36,2-4$.

(57) Apesar de o romance de Heliodoro, como é típico do romance grego em geral, conter elementos que o contextualizam no passado - cf. 1. 9. 1 que faz uma alusão clara ao Areópago de Atenas, ou 1. 10. 1, que refere a celebração das Panateneias -, a verdade é que a existência de ßovkódor, um fenómeno mais tardio, marca um claro anacronismo. Nem Heródoto nem os trágicos que tomaram esta região por cenário referem esta presença. 
(58) Cf. D. S. 1. 43-45, que refere também "os pastores do Nilo". São conhecidas as rebeliões que, no reinado de Marco Aurélio, eclodiram na região do delta, levadas a cabo por estes grupos de salteadores. Dio Cassio (72. 4. 1-2) menciona-os como particularmente activos entre 167-174. Cf. BERTRAND, J. M., "Les boukôloi ou le monde à l'envers", REA 90, 1988, 139-149. SAIID, S., "Rural society in the Greek novel» in S. Swain, ed., Oxford Readings in the Greek novel, Oxford, 1999, 86-88, coloca a hipótese de estes bandos terem resultado de homens enviados pelos faraós para vigiar a costa e controlar o acesso ao Egipto (cf. Strab. 17, 1. 6).

(59) Com uma observação muito próxima do raciocínio analógico de Heródoto, Heliodoro (1. 5. 2) pode descrever: "Estes pântanos são para os lagos o que as margens são para os mares".

(60) SÁNCHEZ, M. B., "Egipto en la novela griega antigua", Habis 23, 1992, 209, sublinha que era sobretudo a zona leste, a região de Pelúsio portanto, a mais relacionada com os Pastores; é Heliodoro o primeiro a associá-los com o delta ocidental. Parece óbvio que se dispersavam por toda a região do Baixo Egipto.

(61) Em 2. 30. 1, Heliodoro distingue deste o tom de pele etíope, de um "negro retinto" (cf. Strab. 15. 1. 24).

(62) Heliodoro (2. 18. 5) refere, por exemplo, que a ilha de Quémis, um território rico e populoso situado no Nilo e num ponto elevado, podia servir de refúgio contra os Pastores, constituindo no delta uma espécie de oásis contra a violência reinante. Heródoto (2. 155-156) menciona esta mesma ilha no Baixo Egipto, perto do lago Buto, na boca sebenítica (cf. Strab. 17. 1. 18), onde havia um grande santuário de Latona.

(63) Um dos quais, de nome Busiris, parece ter ficado célebre pela crueldade com que exerceu o comando (Strab. 17. 1. 19). Cf. ainda Aq. Tac. 3. 9. 3; Heliod. 2. 17. 4.

(64) Heliodoro (6. 3. 4) identifica Bessa como um desses aquartelamentos, lugar ainda não identificado.

(65) Aquiles Tácio (4. 12. 8) arrisca mesmo um nome para uma destas aldeias, Nicóquis, e dá-Ihe dimensões concretas.

(66) Heliodoro (2. 22. 1) fala do grande número de embarcações encostadas à margem do rio, postas à disposição dos viajantes para a travessia do Nilo, mediante pagamento. Aquiles Tácio (4. 18. 3) anima o rio de barcos num cenário festivo: marinheiros a cantar, passageiros a bater palmas, o bailado ondulante das canoas.

(67) BERTRAND (1988) 145 exemplifica como esta mescla de terra e água sempre foi própria da estratégia bélica do Egipto.

(68) Esta versão que Heródoto dá do efeito das cheias, de que são as zonas mais próximas as que primeiro alagam por infiltração (2. 93. 5), parece errada; de facto, as primeiras afectadas são as zonas baixas, ligadas ao Nilo por uma rede de canais de irrigação. 